\title{
Synthesis of Branched Man5 Oligosaccharides and an Unusual Stereochemical Observation
}

\author{
Nardos Teumelsan and Xuefei Huang \\ Department of Chemistry, The University of Toledo, 2801 W. Bancroft Street, MS 602, Toledo, Ohio \\ 43606
}

\section{Abstract}

Branched mannopentaoses were synthesized through two routes. While assembly from the nonreducing end to the reducing end was more convergent with fewer intermediate steps, two diastereomers were obtained. On the other hand, synthesis from the reducing end to the non-reducing end yielded the mannopentaose with the correct stereochemistry as a single isomer. Our results suggest that it is still challenging to reliably predict stereochemical outcome of a glycosylation reaction. It is necessary to thoroughly characterize anomeric configurations of newly formed glycosidic linkages in complex oligosaccharide synthesis.

HIV is one of the most devastating modern diseases. The availability of an effective anti-HIV vaccine may be a good approach to prevent this worldwide epidemic. ${ }^{1-4}$ One of the promising targets for immunogen design is the carbohydrate moieties on HIV-1 envelop protein gp120, ${ }^{5-9}$ as validated by a potent neutralizing human monoclonal antibody 2 G12.10-13

The epitope structures of $2 \mathrm{G} 12$ have recently being characterized to be a series of branched oligomannose residues, as represented by mannopentaose (Man5) 1. ${ }^{11-13}$ Oligomannoses are also primary targets for cyanovirin-N (CVN) ${ }^{14-16}$ an example of HIV envelop binding lectins.

17 Besides their relationship to HIV, branched oligomannoses are integral structural components of asparagines-linked glycan ( $\mathrm{N}$ glycan), one of the major types of post-synthetic protein modifications. ${ }^{18} \mathrm{~N}$-glycans are involved in many fundamental biological processes such as cell differentiation, viral infection, nascent protein processing and tumor migration. 18-23 Therefore, efficient syntheses of branched oligomannoses can provide much needed materials to facilitate ther biological studies.

There are two general approaches to assemble branched oligomannoses such as Man5 1. With the first approach, synthesis is carried out from the non-reducing end to the reducing end (route a in Figure 1). ${ }^{9,23-28} \alpha-1,2$ Linked dimannoside 4 will be synthesized first with the $\alpha$ linkage typically controlled by a participating neighboring group. The dimannoside will then be used in glycosylation of a diol acceptor $\mathbf{5}$ to produce pentasaccharide $\mathbf{8}$. With a mannosyl moiety already installed on the axially oriented O-2 of mannoside 4, one cannot rely on neighboring group participation to control stereochemistries of the two newly formed linkages in $\mathbf{8}$. $\alpha$ linkages should be favored due to the anomeric effect as well as steric hindrance posed by the mannoside moiety on the axial O-2. As an alternative, Man5 can be assembled from the reducing end to the non-reducing end (route b in Figure 1). ${ }^{8,29-34}$ For this approach, a selectively removable protective group such as acetate must be installed on O-2 of the mannosyl donor 2. Upon formation of branched trisaccharide $\mathbf{6}$, the protective group will be removed to generate a diol trisaccharide acceptor 7. Repeating the double glycosylation with mannosyl 
donor $\mathbf{2}$ will lead to pentasaccharide $\mathbf{8}$. Stereochemical outcome of the glycosylations can be controlled by neighboring group participation through this route. Although both of these approaches have been applied to the assembly of branched oligomannosides, except for a few examples, ${ }^{28-31}$ stereochemical proofs of the newly formed glycosidic linkages are often not presented. $8,9,23-27,32-34$

The majority of glycosylation reactions were performed by adding a promoter to a mixture of glycosyl donor and acceptor. 35 Alternatively, a glycosyl donor can be pre-activated in the absence of an acceptor. ${ }^{36-42}$ This can often lead to unique stereochemical outcomes 36,41 and chemoselectivities. ${ }^{37-40}$ Recently, we adapted the pre-activation scheme into a chemoselective glycosylation method, where a thioglycosyl donor is pre-activated in the absence of the acceptor. ${ }^{43-46}$ Upon adding a thioglycosyl acceptor, nucleophilic addition of the acceptor to the activated donor yields a disaccharide product containing a thioaryl aglycon, which can be directly activated for the next round of glycosylation. Because donor activation and addition of acceptor are performed in two distinct steps, the anomeric reactivity of the donor does not need to be higher than that of the acceptor ${ }^{37,38,43-47}$ as required by the traditional reactivity based armed-disarmed chemoselective glycosylation. ${ }^{48}$ We envision that we can apply our pre-activation based method to convergently assemble Man5 using building blocks $9,4310^{43}$ and $\mathbf{1 1}$.
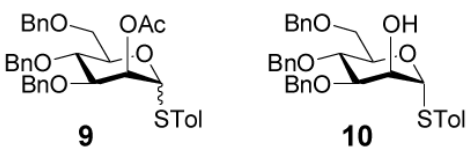

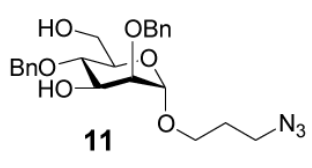

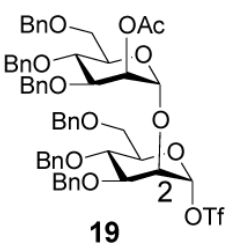

19

Synthesis of the diol acceptor 11 started from the known azidopropyl $\alpha$-mannoside $\mathbf{1 2}$ 49,50 (Scheme 1). Selective protection of the 3 and 6 hydroxyl groups led to disilyl ether $\mathbf{1 3}$ in $66 \%$ yield. ${ }^{11}$ Benzylation of $\mathbf{1 3}$ followed by removal of the tertbutyldimethyl silyl (TBDMS) ethers gave acceptor 11. The presence of free 3 and 6-OH in $\mathbf{1 1}$ was ascertained by NMR analysis of its acetylation product.

Pre-activation of thiomannosyl donor 9 by promoter $p$-TolSOTf, ${ }^{41,43,51}$ formed in situ through reaction of $p$-TolSCl and AgOTf, was followed by addition of acceptor $\mathbf{1 0}$ and a sterically bulky base 2,4,6-tri-tertbutyl-pyrimidine (TTBP), ${ }^{52}$ leading to disaccharide 14 in $63 \%$ yield (Scheme 2). The structure of $\mathbf{1 4}$ was confirmed by one bond coupling constants between the anomeric carbon and hydrogen atoms $\left({ }^{1} \mathrm{~J}_{\mathrm{CH}}=172.5\right.$ and $\left.171.5 \mathrm{~Hz}\right) .{ }^{53,54} \mathrm{In}$ addition, the presence of carbonyl groups in $\mathbf{1 4}$ was determined by ${ }^{13} \mathrm{C}-\mathrm{NMR}(\delta=170.4 \mathrm{ppm})$. The anomeric reactivity of donor $\mathbf{9}$ is lower than that of acceptor $\mathbf{1 0}$ due to the presence of acetate on $\mathrm{O} 2$ of $\mathbf{9}$. With the traditional armed-disarmed chemoselective glycosylation approach, ${ }^{48}$ direct glycosylation of acceptor 10 by donor 9 was not possible. ${ }^{9,11}$ Instead, the thioglycosyl donor had to be hydrolyzed into a hemiacetal followed by conversion into trichloroacetimidate donor. ${ }^{11}$ Selective activation of the imidate donor over the thioglycosyl acceptor then gave thioglycosyl disaccharide. The usage of the pre-activation procedure enables us to bypass the need for aglycon transformation, thus simplifying synthetic designs and improving overall synthetic efficiencies.

With disaccharide 14 prepared, double glycosylation of diol acceptor 11 by 14 was performed with the $p$-TolSCl/AgOTf promoter system (Scheme 2). Two compounds were formed in a ratio of 3:7 with slight polarity difference shown by TLC. After careful silica gel chromatography separation, to our surprise, the two products were found to have identical molecular weights corresponding to pentamannoside, indicating that they are diastereomers. 
The less polar minor component $\mathbf{1 5 \alpha}$ was obtained in $14 \%$ yield with ${ }^{1} \mathrm{~J}_{\mathrm{CH}}$ between anomeric carbons and hydrogens determined to be 169.9, 170.7, 170.9, 171.6 and $171.6 \mathrm{~Hz}$ confirming that all five glycosidic linkages are $\alpha .53,54$ The more polar major product $\mathbf{1 5 \beta}(33 \%)$ have ${ }^{1} \mathrm{~J}_{\mathrm{CH}}$ between anomeric carbons and hydrogens of $162.4,162.9,172.8,173.6$, and 173.6 $\mathrm{Hz}$, suggesting both of the newly formed glycosidic linkages are $\beta$ ! Glycosylation of acceptor 11 by 14 using $N$-iodosuccinimide and triflic acid as the promoter ${ }^{11}$ failed to yield any pentamannosides in our hands. Instead, multiple decomposition products were observed presumably due to acid sensitivity of the oligosaccharide products.

In order to confirm our structure assignment, we investigated the alternative route for Man5 construction (Scheme 3a). Double glycosylation of diol 11 by donor 9 provided trimannan 16 in $60-63 \%$ yield. ${ }^{13} \mathrm{C}$-NMR of $\mathbf{1 6}$ has two resonances at $170.4,170.6 \mathrm{ppm}$ and ${ }^{1} \mathrm{~J}_{\mathrm{CH}}$ between anomeric protons and carbons are $169.5,172.1$, and $172.1 \mathrm{~Hz}$ proving it is not an orthoester and both new glycosidic linkages are $\alpha$. Removal of the acetates with $\mathrm{NaOMe}$ produced trisaccharide diol 17 in $77 \%$ yield. Double glycosylation of diol $\mathbf{1 7}$ by donor 9 led to pentamannoside $\mathbf{1 5 \alpha}$ in $60 \%$ yield, which was found to have identical polarity, NMR and molecular weight as $\mathbf{1 5} \boldsymbol{\alpha}$ synthesized from the non-reducing end to the reducing end (Scheme 2). No $15 \beta$ was obtained through this route, demonstrating that anomeric configurations of $15 \boldsymbol{\alpha}$ are stable under the reaction conditions.

Deprotection of pentamannoside $\mathbf{1 5} \boldsymbol{\alpha}$ was quite straightforward (Scheme $3 b$ ). Removal of the two acetates by sodium methoxide followed by Staudinger reduction of the azido moiety and catalytic hydrogenation ${ }^{46}$ produced fully deprotected Man5 18 in $75 \%$ overall yield for the three steps. The aminopropyl moiety at the reducing end can be utilized for future bioconjugation and the development of anti-HIV vaccine studies.

The fact that the major product synthesized from the non-reducing end to the reducing end direction is $\mathbf{1 5 \beta}$ is surprising considering that 1 ) reaction is carried out in diethyl ether, an ethereal solvent well known to favor the generation of thermodynamically more stable, axial glycoside product; $55-57$ and 2) the anomeric effect and the steric hindrance posed by the bulky mannoside moiety on the axial O-2 of disaccharide 14 should disfavor the equatorial glycoside. Crich and coworkers have developed a powerful methodology for $\beta$-mannoside formation using 4,6-benzylidene protected mannosyl donors. ${ }^{41,47} \alpha$-Mannosyl triflate was identified as the resting state of the reactive intermediate, ${ }^{58}$ with SN2 like displacement of the anomeric triflate through an exploded transition state leading to the $\beta$ product. ${ }^{59}$ Benzylidene moiety was found to be crucial to conformationally locked the pyranoside ring into chair conformation, disfavoring oxacarbenium ion formation, while electron withdrawing protective groups on O-2 were shown to have a similar effect. ${ }^{60}$ The generation of Man5 $15 \beta$ in our synthesis may be rationalized by the formation of $\alpha$-mannosyl triflate intermediate 19 upon activation of disaccharide 14. With the presence of the carbohydrate moiety on $\mathrm{O} 2$, which can be viewed as an electron withdrawing 61 non-participating group, the $\alpha$-mannosyl triflate intermediate 19 may be stabilized. The $\mathrm{O} 2$ mannosyl unit on 19 can rotate around the $\mathrm{O} 2$ and $\mathrm{C} 2$ bond, with the large pyranoside ring pointing away from the anomeric position. This can reduce the steric hindrance of the $\beta$ face posed by the pyranoside ring allowing formation of the $\beta$ linkage. The formation of $\alpha$ linkage may be disfavored due to the mismatch 62 of 19 with the acceptor at the transition state. 63

Our results suggest that factors controlling stereochemistry of glycosylation especially in the absence of neighboring group participation are still not well understood. Although assembly of branched oligomannosides from the direction of non-reducing end to the reducing end is a popular approach, caution needs to be taken regarding stereochemical outcome of the reaction. Anomeric effect and steric hindrance are not dependable control of stereochemistry. For the 
development of a reliable and general automated glycosylation method, stereochemical control remains a significant challenge.

\section{Experimental Section}

3-Azidopropyl 2-O-acetyl-3,4,6-tri-O-benzyl-D-mannopyranosyla(1 $\rightarrow 2)$-3,4,6-tri-O-benzyl-Dmannopyranosyla $(1 \rightarrow 3)$-(2-O-acetyl-3,4,6-tri-O-benzyl-D-mannopyranosyla(1 $\rightarrow 2)$-3,4,6-triO-benzyl-D-mannopyranosyla $(1 \rightarrow 6))$-2,4-di-O-benzylaD-mannopyranoside (15a) and 3azidopropyl 2-O-acetyl-3,4,6-tri-O-benzyl-D-mannopyranosyla(1 $\rightarrow 2)$-3,4,6-tri-O-benzyl-Dmannopyranosyl- $\beta$-(1 $\rightarrow 3)$-(2-O-acetyl-3,4,6-tri-O-benzyl-D-mannopyranosyla(1/2)-3,4,6-triO-benzyl-D-mannopyranosyl- $\beta$-(1 $\rightarrow 6))$-2,4-di-O-benzylaD-mannopyranoside (15 $\beta$ ).

Donor $14(0.180 \mathrm{~g}, 0.175 \mathrm{mmol})$ and acceptor 11 (0.4 eq, $0.033 \mathrm{~g}, 0.070 \mathrm{mmol})$ were azeotropically dried over toluene together three times and mixed with freshly activated molecular sieves MS $4 \AA$ ( $200 \mathrm{mg})$ in diethyl ether $(5 \mathrm{~mL})$. The mixture was stirred at room temperature for 30 minutes and cooled to $-78{ }^{\circ} \mathrm{C}$, which was followed by addition of TTBP $(0.043 \mathrm{~g}, 0.175 \mathrm{mmol})$ and a solution of $\operatorname{AgOTf}(0.135 \mathrm{~g}, 0.53 \mathrm{mmol}, 3 \mathrm{eq})$ dissolved in $\mathrm{Et}_{2} \mathrm{O}$ $(2 \mathrm{~mL})$ without touching the wall of the flask. After 5 minutes, orange colored $p$-TolSCl (25 $\mu \mathrm{L}, 0.175 \mathrm{mmol}$ ) was added through a microsyringe. Since the reaction temperature was lower than the freezing point of $p$-TolSCl, $p$-TolSCl was added directly into the reaction mixture to prevent it from freezing on the flask wall. The characteristic yellow color of $p$-TolSCl in the reaction dissipated rapidly within a few seconds indicating depletion of $p$-TolSCl. The reaction mixture was warmed to $\mathrm{H} 20{ }^{\circ} \mathrm{C}$ under stirring over 90 minutes. The reaction was quenched with triethylamine, diluted with $\mathrm{CH}_{2} \mathrm{Cl}_{2}(30 \mathrm{~mL})$ and filtered over Celite. The Celite was further washed with $\mathrm{CH}_{2} \mathrm{Cl}_{2}$ until no organic compounds were observed in the filtrate by TLC. All $\mathrm{CH}_{2} \mathrm{Cl}_{2}$ solutions were combined and washed twice with saturated aqueous solution of $\mathrm{NaHCO}_{3}(20 \mathrm{~mL})$ and twice with water $(10 \mathrm{~mL})$. The organic layer was collected and dried over $\mathrm{Na}_{2} \mathrm{SO}_{4}$. After removal of the solvent, the yellowish residue was purified by silica gel chromatography (toluene $/ \mathrm{CH}_{2} \mathrm{Cl}_{2}$ /acetone $\left.=1.5: 0.02: 0.02\right)$ to give pentasaccharides $\mathbf{1 5} \boldsymbol{\alpha}$ ( 22 $\mathrm{mg})$ and $\mathbf{1 5 \beta}(51.5 \mathrm{mg})$ in $47 \%$ yield. 15 $\boldsymbol{\beta}:[\alpha]_{\mathrm{D}}^{25}+16\left(\mathrm{c}=1.0, \mathrm{CH}_{2} \mathrm{Cl}_{2}\right)$. H-NMR $(600 \mathrm{MHz}$, $\left.\mathrm{CDCl}_{3}\right) \delta 1.20-1.24(\mathrm{~m}, 3 \mathrm{H}), 1.51-1.52(\mathrm{~m}, 2 \mathrm{H}), 2.07(\mathrm{~s}, 3 \mathrm{H}), 2.09(\mathrm{~s}, 3 \mathrm{H}), 3.30-3.34(\mathrm{~m}, 2 \mathrm{H})$, 3.42-3.44 (m, 1H), 3.49-3.61 (m, 7H), 3.65-3.72 (m, 4H), 3.78-3.84 (m, 6H), 3.87-3.94 (m, $5 \mathrm{H}), 3.97-4.03(\mathrm{~m}, 4 \mathrm{H}), 4.21-4.26(\mathrm{~m}, 3 \mathrm{H}), 4.32-4.43(\mathrm{~m}, 7 \mathrm{H}), 4.44-4.65(\mathrm{~m}, 15 \mathrm{H}), 4.66-4.75$ $(\mathrm{m}, 2 \mathrm{H}), 4.77-4.85(\mathrm{~m}, 4 \mathrm{H}), 5.06(\mathrm{~s}, 1 \mathrm{H}), 5.13-5.15(\mathrm{~m}, 1 \mathrm{H}), 5.50(\mathrm{~s}, 1 \mathrm{H}), 5.57(\mathrm{~d}, J=1.8 \mathrm{~Hz}$, $1 \mathrm{H}), 7.08-7.34(\mathrm{~m}, 70 \mathrm{H}) ;{ }^{13} \mathrm{C}-\mathrm{NMR}\left(150 \mathrm{MHz}, \mathrm{CDCl}_{3}\right): \delta 21.40,21.43,22.9,28.8,29.9,30.5$, $48.5,64.5,68.5,68.8,69.0,69.07,69.09,69.5,69.7,71.5,72.0,72.08,72.14,72.21,72.28$, $72.33,72.5,72.8,73.4,73.52,73.55,74.2,73.6,74.5,74.84,74.87,74.93,75.04,75.24,75.26$, $75.32,75.9,76.0,77.0,77.2,77.5,77.7,78.3,78.8,82.5,97.0\left({ }^{1} J_{\mathrm{H} 1, \mathrm{C} 1}=162.4 \mathrm{~Hz}\right), 99.1$

$\left({ }^{1} J_{\mathrm{H} 1, \mathrm{C} 1}=173.6 \mathrm{~Hz}\right), 99.5\left({ }^{1} J_{\mathrm{H} 1, \mathrm{C} 1}=173.6 \mathrm{~Hz}\right), 100.9\left({ }^{1} J_{\mathrm{H} 1, \mathrm{C} 1}=162.9 \mathrm{~Hz}\right), 101.1$

$\left({ }^{1} J_{\mathrm{H} 1, \mathrm{C} 1}=172.8 \mathrm{~Hz}\right), 127.26,127.36,127.39,127.55,127.61,127.65,127.67,127.69,127.72$, $127.76,127.82,127.86,127.89,127.94,127.97,128.09,128.11,128.18,128.20,128.25$, $128.28,128.32,128.34,128.38,128.39,128.44,128.48,128.49,128.50,128.54,128.56$, $128.58,128.61,128.63,128.66,128.69,128.75,128.82,128.86,138.17,138.23,138.35$, $138.38,138.42,138.45,138.57,138.61,138.7,138.8,139.1,170.3,170.4$. MS (ESI) $\mathrm{m} / z$ calcd for $\mathrm{C}_{135} \mathrm{H}_{145} \mathrm{~N}_{3} \mathrm{NaO}_{28}[\mathrm{M}+\mathrm{Na}]^{+}: 2279.0$; found: 2279.8 . HRMS: $\mathrm{m} / z$ calcd for

$\mathrm{C}_{135} \mathrm{H}_{145} \mathrm{~N}_{3} \mathrm{NaO}_{28}[M+\mathrm{Na}]^{+}:$2278.9912; found: 2278.9900. 15 $\alpha[\alpha]_{\mathrm{D}}^{25}+17(\mathrm{c}=1.0$, $\left.\mathrm{CH}_{2} \mathrm{Cl}_{2}\right) .{ }^{1} \mathrm{H}-\mathrm{NMR}\left(600 \mathrm{MHz}, \mathrm{CDCl}_{3}\right) \delta 1.64-1.66(\mathrm{~m}, 2 \mathrm{H}), 2.10(\mathrm{~s}, 6 \mathrm{H}), 3.18-3.34(\mathrm{~m}, 4 \mathrm{H})$, $3.45-3.49(\mathrm{t}, J=11.4 \mathrm{~Hz}, 2 \mathrm{H}), 3.58-3.67(\mathrm{~m}, 8 \mathrm{H}), 3.77-3.81(\mathrm{~m}, 4 \mathrm{H}), 3.84-3.85(\mathrm{~m}, 2 \mathrm{H})$, 3.88-4.07 (m, 12H), 4.24-4.27 (d, $J=10.8 \mathrm{~Hz}, 1 \mathrm{H}), 4.34-4.47(\mathrm{~m}, 8 \mathrm{H}), 4.50-4.69(\mathrm{~m}, 15 \mathrm{H})$, $4.73(\mathrm{~s}, 1 \mathrm{H}), 4.78-4.87(\mathrm{~m}, 4 \mathrm{H}), 4.93(\mathrm{~s}, 1 \mathrm{H}), 5.06-5.06(\mathrm{~m}, 2 \mathrm{H}), 5.16(\mathrm{~s}, 1 \mathrm{H}), 5.51(\mathrm{~s}, 2 \mathrm{H})$, 7.09-7.32 (m, 70H). ${ }^{13} \mathrm{C}-\mathrm{NMR}\left(150 \mathrm{MHz}, \mathrm{CDCl}_{3}\right): \delta 21.4,29.0,48.5,64.5,66.7,68.4,68.8$, 69.0, 69.1, 69.8, 71.6, 72.0, 72.11, 72.19, 72.25, 72.9, 73.4, 73.56, 73.60, 74.2, 74.4, 74.6, 74.7, $74.8,74.9,75.1,75.3,75.4,77.0,77.3,77.6,77.8,78.0,78.3,78.4,79.4,79.9,97.2\left({ }^{1} J_{\mathrm{H} 1}, \mathrm{C} 1\right.$ 
$=169.9 \mathrm{~Hz}), 99.3\left({ }^{1} J_{\mathrm{H} 1, \mathrm{C} 1}=170.9 \mathrm{~Hz}\right), 99.5\left({ }^{1} J_{\mathrm{H} 1, \mathrm{C} 1}=171.6 \mathrm{~Hz}\right), 99.8\left({ }^{1} J_{\mathrm{H} 1, \mathrm{C} 1}=171.6\right.$ $\mathrm{Hz}), 101.4\left({ }^{1} J_{\mathrm{H} 1, \mathrm{C} 1}=170.7 \mathrm{~Hz}\right), 127.2,127.5,127.70,127.78,127.84,127.95,127.99,128.02$, $128.29,128.42,128.47,128.49,128.55,128.59,128.71,138.24,138.27,138.37,138.44$, 138.46, 138.51, 138.63, 138.72, 138.78, 138.80, 170.37, 170.40. HRMS: $\mathrm{m} / \mathrm{z}$ calcd for $\mathrm{C}_{135} \mathrm{H}_{145} \mathrm{~N}_{3} \mathrm{NaO}_{28}[M+\mathrm{Na}]^{+}:$2278.9912; found: 2278.9949 .

\section{Supplementary Material}

Refer to Web version on PubMed Central for supplementary material.

\section{Acknowledgment}

We are grateful for financial supports from the University of Toledo, the National Institutes of Health (R01-GM-72667) and a Research Supplement to Promote Diversity in Health-Related Research (R01 GM72667-S1).

\section{References}

(1). Girard MP, Osmanov SK, Kieny MP. Vaccines 2006;24:4062-4081.

(2). Gallo RC. Lancet 2005;366:1894-1898. [PubMed: 16310557]

(3). McMichael AJ, Hanke T. Nat. Med 2003;9:874-880. [PubMed: 12835708]

(4). Letvin NL, Walker BD. Nat. Med 2003;9:861-866. [PubMed: 12835706]

(5). Scanlan CN, Offer J, Zitzmann N, Dwek RA. Nature 2007;446:1038-1045. [PubMed: 17460665]

(6). Wang L-X. Curr. Opin. Drug Disc. Dev 2006;9:194-206.

(7). Ni J, Song H, Wang Y, Stamatos NM, Wang L-X. Bioconjugate Chem 2006;17:493-500.

(8). Geng X, Dudkin VY, Mandal M, Danishefsky SJ. Angew. Chem. Int. Ed 2004;43:2562-2565.

(9). Lee H-K, Scanlan CN, Huang C-Y, Chang AY, Calarese DA, Dwek RA, Rudd PM, Burton DR, Wilson IA, Wong C-H. Angew. Chem. Int. Ed 2004;43:1000-1003.

(10). McReynolds KD, Gervay-Hague J. Chem. Rev 2007;107:1533-1552. [PubMed: 17439183]

(11). Calarese DA, Lee H-K, Huang C-Y, Best MD, Astronomo RD, Stanfield RL, Katinger H, Burton DR, Wong CH, Wilson IA. Proc. Nat. Acad. Sci. USA 2005;102:13372-13377. [PubMed: 16174734]

(12). Calarese DA, Scanlan CN, Zwick MB, Deechongkit S, Mimura Y, Kunert R, Zhu P, Wormald MR, Stanfield RL, Roux KH, Kelly JW, Rudd PM, Dwek RA, Katinger H, Burton DR, Wilson IA. Science 2003;300:2065-2071. [PubMed: 12829775]

(13). Scanlan CN, Pantophlet R, Wormald MR, Ollmann Saphire E, Stanfield R, Wilson IA, Katinger H, Dwek RA, Rudd PM, Burton DR. J. Virol 2002;76:7306-7321. [PubMed: 12072529]

(14). Shenoy SR, Barrientos LG, Ratner DM, O'Keefe BR, Seeberger PH, Gronenborn AM, Boyd MR. Chem. Biol 2003;9:1109-1118. [PubMed: 12401495]

(15). Botos I, Wlodawer A. Cell. Mol. Life Sci 2003;60:277-287. [PubMed: 12678493]

(16). Bewley CA, OteroQuintero S. J. Am. Chem. Soc 2001;123:3892-3902. [PubMed: 11457139]

(17). Botos I, Wlodawer A. Prog. Biophys. Mol. Biol 2005;88:233-282. [PubMed: 15572157]

(18). Dwek RA. Chem. Rev 1996;96:683-720. [PubMed: 11848770]

(19). Ernst, B.; Hart, GW.; Siney, P., editors. Carbohydrates in Chemistry and Biology. Wiley-VCH; Weinheim; 2000.

(20). Moremen KW, Molinari M. Curr. Opin. Struc. Biol 2006;16:592-599.

(21). Natsuka S. Trends Glycosci. Glycotech 2005;17:229-236.

(22). Schachter H. J. Clin. Invest 2001;108:1579-1582. [PubMed: 11733552]

(23). Matsuo I, Wada M, Manabe S, Yamaguchi Y, Otake K, Kato K, Ito Y. J. Am. Chem. Soc 2003;125:3402-3403. [PubMed: 12643681]

(24). Totani K, Ihara Y, Matsuo I, Koshino H, Ito Y. Angew. Chem. Int. Ed 2005;44:7950-7954.

(25). Xing Y, Ning J. Tetrahedron Assym 2003;14:1275-1283.

(26). Green L, Hinzen B, Ince SJ, Langer P, Ley SV, Warriner SL. Synlett 1998:440-442. 
(27). Düffels A, Ley SV. J. Chem. Soc. Perkin Trans. 1 1999:375-378.

(28). Zhu Y, Kong F. Synlett 2001:1217-1220.

(29). Blattner R, Furneaux RH, Ludewig M. Carbohydr. Res 2006;341:299-321. [PubMed: 16364272]

(30). Lam SN, Gervay-Hague J. J. Org. Chem 2005;70:8772-8779. [PubMed: 16238308]

(31). Srivastava OP, Hindsgaul O. J. Org. Chem 1987;52:2869-2875.

(32). Ratner DM, Plante OJ, Seeberger PH. Eur. J. Org. Chem 2002:826-833.

(33). Du Y, Zhang M, Kong F. Tetrahedron 2001;57:1757-1763.

(34). Jiang L, Chan T-H. Can. J. Chem 2005;83:693-701.

(35). Wang Y, Ye X-S, Zhang L-H. Org. Biomol. Chem 2007;5:2189-2200. [PubMed: 17609746]and references cited therein.

(36). Kim J-H, Yang H, Park J, Boons G-J. J. Am. Chem. Soc 2005;127:12090-12097. [PubMed: 16117550]

(37). Yamago S, Yamada T, Ito H, Hara O, Mino Y, Maruyama T, Yoshida J-I. Chem. Eur. J 2005;11:6159-6194.

(38). Codée JDC, van den Bos LJ, Litjens REJN, Overkleeft HS, van Boeckel CAA, van Boom JH, van der Marel GA. Tetrahedron 2004;60:1057-1064.

(39). Yamago S, Yamada T, Maruyama T, Yoshida J-I. Angew. Chem. Int. Ed 2004;43:2145-2148.

(40). Nguyen HM, Poole JL, Gin DY. Angew. Chem. Int. Ed 2001;40:414-417.

(41). Crich D, Sun S. Tetrahedron 1998;54:8321-8348.

(42). Kahne D, Walker S, Cheng Y, Van Engen D. J. Am. Chem. Soc 1989;111:6881-6882.

(43). Huang X, Huang L, Wang H, Ye X-S. Angew. Chem. Int. Ed 2004;42:5221-5224.

(44). Huang L, Huang X. Chem. Eur. J 2007;13:529-540.

(45). Huang L, Wang Z, Li X, Ye X-S, Huang X. Carbohydr. Res 2006;341:1669-1679. [PubMed: 16442505]

(46). Wang Z, Zhou L, El-Boubbou K, Ye X-S, Huang X. J. Org. Chem 2007;72in press

(47). Crich D, Li W, Li H. J. Am. Chem. Soc 2004;126:15081-15086. [PubMed: 15548005]

(48). Koeller KM, Wong C-H. Chem. Rev 2000;100:4465-4493. [PubMed: 11749355] and references cited therein.

(49). Ladmiral V, Mantovani G, Clarkson GJ, Cauet S, Irwin JL, Haddleton DM. J. Am. Chem. Soc 2006;128:4823-4830. [PubMed: 16594719]

(50). Hayes W, Osborn HMI, Osborne SD, Rastallb RA, Romagnoli B. Tetrahedron 2003;59:7983-7996.

(51). Martichonok V, Whitesides GM. J. Org. Chem 1996;61:1702-1706. [PubMed: 11667039]

(52). Crich D, Smith M, Yao Q, Picione J. Synthesis 2001:323-326.

(53). Duus JØ, Gotfredsen CH, Bock K. Chem. Rev 2000;100:4589-4614. [PubMed: 11749359]

(54). Bock K, Pedersen C. J. Chem. Soc. Perkin Trans. 2 1974:293-297.

(55). Chiba H, Funasaka S, Mukaiyama T. Bull. Chem. Soc. Jpn 2003;76:1629-1644.

(56). Adinolfi M, Barone G, Iadonisi A, Schiattarella M. Tetrahedron Lett 2002;43:5573-5577.

(57). Wulff G, Rohle G. Angew. Chem. Int. Ed 1974;13:157-170.

(58). Crich D, Sun S. J. Am. Chem. Soc 1997;119:11217-11223.

(59). Crich D, Chandrasekera S. Angew. Chem. Int. Ed 2004;43:5386-5389.

(60). Crich D, Picione J. Org. Lett 2003;5:781-784. [PubMed: 12605514]

(61). Zhang Z, Ollman IR, X.-S. Ye, Wischnat R, Baasov T, Wong C-H. J. Am. Chem. Soc 1999;121:734753.

(62). Fraser-Reid B, López JC, Gómez AM, Uriel C. Eur. J. Org. Chem 2004:1387-1395.

(63). Spijker NM, Van Boeckel CAA. Angew. Chem. Int. Ed 1991;30:180-183. 


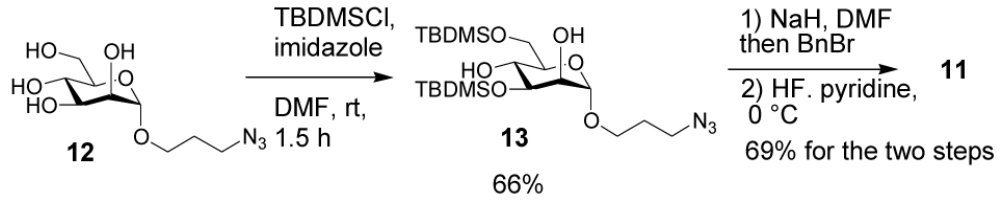

Scheme 1.

Synthesis of diol acceptor 11. 

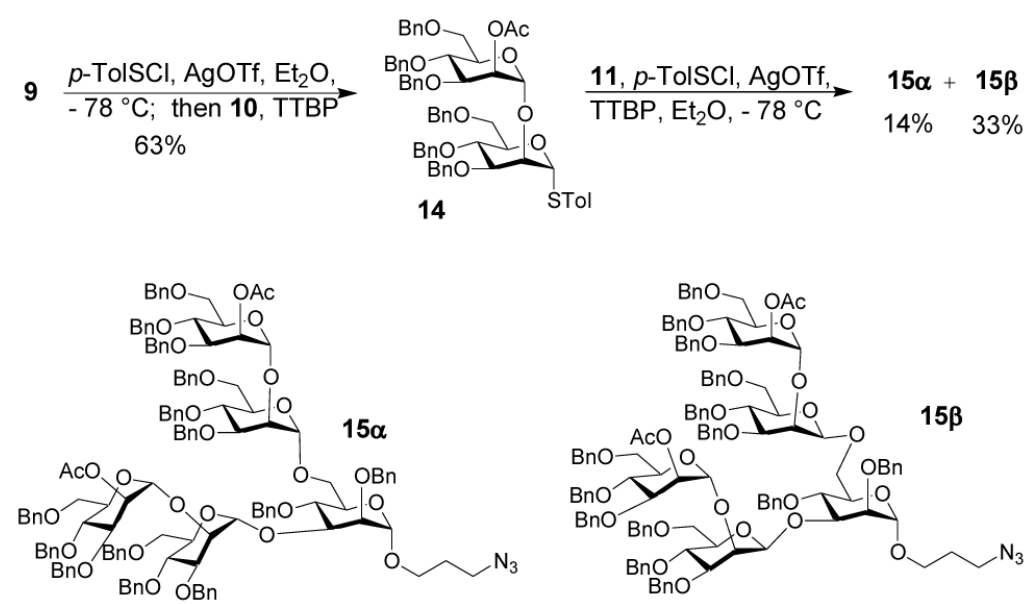

Scheme 2.

Synthesis of Man5 from the non-reducing end to the reducing end. 
a)

$$
9
$$

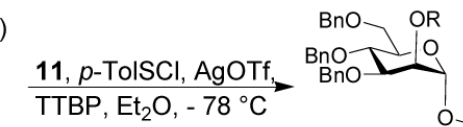

$60-63 \%$

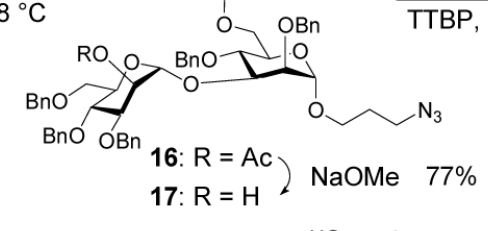

b)

1) $\mathrm{NaOMe}$

2) $\mathrm{PMe}_{3}, \mathrm{NaOH}, \mathrm{THF}$

$15 \alpha \stackrel{\text { 3) } \mathrm{H}_{2}, \mathrm{Pd} / \mathrm{C}, \mathrm{HOAc}, \mathrm{CH}_{3} \mathrm{OH}, \mathrm{H}_{2} \mathrm{O}}{75 \% \text { for the three steps }}$


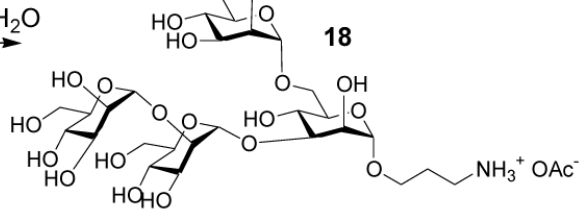

Scheme 3.

Synthesis of Man5 from the reducing end to the non-reducing end. 


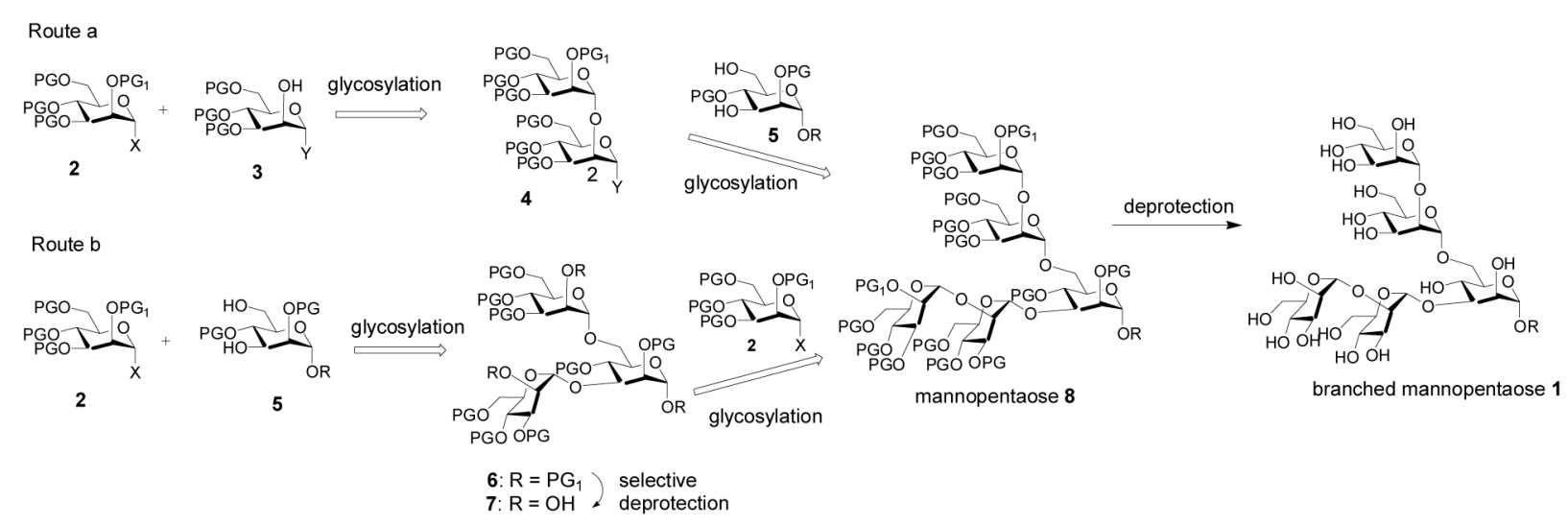

Figure 1.

Two general approaches for synthesis of branched mannopentaoses. 